\title{
Bakım Veren Bireylere Yönelik Geliştirilen Bireysel Ergoterapi Eğitim Programının Yaşam Kalitesine ve Bakım Veren Yüküne Yönelik Etkinliğinin Incelenmesi
}

Investigation of the Effectiveness of Person Centered Occupational Therapy Education Program for Caregivers on Quality of Life and Caregivers Burden

Barkın KÖSE ${ }^{1}$, Esra $A K I^{2}$

${ }^{1}$ Uz. Erg., Hacettepe Üniversitesi Sağlık Bilimleri Fakültesi Ergoterapi Bölümü, Ankara

${ }^{2}$ Prof.Dr., Hacettepe Üniversitesi Sağlık Bilimleri Fakültesi Ergoterapi Bölümü, Ankara

\section{öz}

\begin{abstract}
Amaç: Çalışmanın amacı bakım veren bireylerin bakım verme işinden kaynaklanan sorunlarını tespit etmek ve sorunların giderilmesine yönelik eğitim modeli oluşturmaktır. Gereç ve Yöntem: Bakım veren bireylerin bakım verme işine başladıktan sonra yaşadıkları problemlerin tespit etmek için, bakım verenlerle yüz yüze görüşme yapıldı. Yüz yüze görüşmenin ardından bireylere yaşam kalitelerini belirlemek için Notthingam Sağlık Profili, depresyon ve kaygı düzeylerinin tespiti için Beck Depresyon ve Anksiyete Envanterleri, bakım veren yükünün tespiti içinde Zarit Yük Indeksi uygulandı. Bu değerlendirme testleri analiz edilerek bireysel eğitim programları hazırlandı ve bakım veren bireylere 8 hafta boyunca haftada 1 saat şeklinde uygulandı. Ardından değerlendirme testleri ikinci kez uygulandı. Veriler SPSS 22.0 programı kullanılarak yorumlandı. Sonuçlar: Bakım veren bireylerin eğitim programı öncesi-sonrası yaşam kalitelerinde, depresyon düzeylerinde ve bakım verme işinden kaynaklı yüklenme düzeyleri arasında istatistiksel olarak anlamlı $(p<0,05)$ fark bulundu. Tartışma: Bakım veren bireylerin bakım verme işinden kaynaklı etkilenimler günlük yaşamlarını olumsuz etkilemekte ve yaşam kalitelerini düşürmektedir. Çalışmamızın sonucunda, bakım veren bireyler için hazırlanan bireysel ergoterapi eğitim programlarının problemlerin çözümü noktasında etkin olduğu bulunuldu. Bu çalışmaların daha geniş gruplarla, kanıt değerliliği artırılarak yaygınlaştırılması, bakım veren bireylerin yaşadığı sorunların çözümü ve toplum temelli projelerin geliştirilmesi noktasında önemli olduğu düşünülmektedir.
\end{abstract}

Anahtar Kelimeler: Bakıcı; Sağık Eğitimi; Yaşam Kalitesi; İ̧ Uğraşı Terapisi

\section{ABSTRACT}

Purpose: The aim of this study is to identify the problems caregivers face in the process of caregiving and to create an educational program to overcome these problems. Material and Methods: A face-toface interview was held with the caregivers to determine the problems they experienced after the caregivers started their care. After the face to face interview, individuals assessed in Nottingham Health Profile to describe quality of life, Beck Depression and Anxiety Inventory to describe depression and anxiety levels, Zarit Burden Interviews to describe caregiver's burden level. These assessment tests were analyzed and individual training programs were prepared and administered to caregivers as 1 hour per week for 8 weeks. Then, the evaluation tests were applied for the second time. Data were interpreted using SPSS 22.0 program. Results: There were statistically significant differences between pre-post results of caregivers' level of quality of life, level of depression and level of caregiver burden $(p<0.05)$. Conclusion: Affected by the caregiving work of caregivers adversely affect their daily lives and decrease their quality of life. As a result of our study, it was concluded that the individual occupational therapy training programs prepared for caregivers were effective in solving the problems. These studies are thought to be important in wider groups, increasing the value of evidence, dissolving the problems of caregivers and developing community based projects.

Key Words: Caregiver; Health Education; Quality of Life; Occupational Therapy 
Her yıl yaklaşık olarak 800.000'den fazla insan inme, spinalkord yaralanmaları ve konjenital malformasyonlar gibi fiziksel fonksiyonlarını etkileyen birçok hastalık geçirmektedir (Faria, 1998). Yaşanılan bu hastalık süreci, problemler ve bakım intiyacı birbiriyle ilişkilidir.

Bakım vermek; bir bireyin beslenme, giyinme, kişisel temizlik gibi gereksinimlerini üstlenme şeklinde tanımlanmaktadır. Bakım verme formal ya da informal olmak üzere iki şekilde incelenmektedir. Formal bakım verme; evde ya da kurumda sağlık bakımı ve kişisel bakım hizmetlerini sunan meslek grupları tarafından verilen profesyonel bakım verme hizmetidir. Evde formal bakım sağlayanlar daha çok ergoterapist, fizyoterapist, hemşire, sosyal hizmet uzmanı, diyetisyen ve evde bakım yardımcılarıdır (Zarit, Todd, \& Zarit, 1986). İnformal ya da uzmanlık gerektirmeyen bakım verme ise bakıma intiyaç duyan kişinin bir yakını tarafından yardım etme fikriyle üstlenilen durum şeklinde tanımlanmaktadır (Lui, Lee, Greenwood ve ark, 2012). Informal bakım verenler ücret almayan, evde bakım sağlayan aile üyeleri veya arkadaşlardan oluşmaktadır. Bakıma intiyacı olan bireyler için informal bakım vermeyi aile içinde çoğu zaman anne, eş ya da evlat üstlenmektedir. Bu durumda bakım verme hizmetinin ağırlıklı olarak evlerde gerçekleştirildiği sonucuna varılmaktadır (Bergström, Eriksson, von Koch ve ark, 2011).

Özellikle fiziksel özre sahip bireylere bakım vermek daha fazla önem kazanmaktadır. Çünkü fiziksel özürlü birey çoğu zaman evde, okulda ve çevrede transferler sırasında başka kişilerin yardımına intiyaç duymaktadır. Bu bakım sürecinde de bakım veren birey çeşitli seviyelerde etkilenimlere maruz kalmaktadır. Bakım verenin bu etkilenimi çoğu zaman fiziksel olmaktadır. Bunun sonucunda da bireyde başta kas-iskelet sistemi rahatsızlıkları olmak üzere çeşitli problemler görülebilmektedir (Chang, Chiou, \& Chen, 2010; Morimoto, Schreiner, \& Asano, 2003).

Bakım verenin fiziksel sağlığının yanı sıra psikososyal sağlığı da olumsuz etkilenmektedir. Bu durum sıklıkla depresyon ve anksiyete şeklinde görülmektedir. Depresyon ve anksiyete düzeyinin yüksek olmasına bağlı olarak bireylerin yaşam kaliteleri olumsuz yönde etkilenmektedir. Yaşam kalitesi, kişinin kendi yaşadığı kültür ve değer sistemleri çerçevesinde, amaçları, beklentileri, standartları ve ilgileri ile ilişkili olarak yaşamdaki durumunu algılamasıdır (Toseland, Rossiter, Peak ve ark, 1990). Bununla birlikte bakım verenlerin yaşam kalitesinin etkilenmesinde, bakım intiyacı olan bireyin motor performans düzeyi, iletişim problemleri ve bireyin sahip olduğu sosyal rollerini yerine getirmedeki güçlükleri de etkili olabilir (Bevans \& Sternberg, 2012; Chang ve ark, 2010; Given, Given, Stommel ve ark, 1992; Thompson Jr, Futterman, Gallagher-Thompson ve ark, 1993).

Bakım verme yüküne maruz kalan bireylerin yaşam kalitesini ve iyilik halini artırabilmek için kişiçevre-aktivite perspektifinde bütüncül yaklaşımla yöntemler geliştirilebilir. Bu yöntemler;

Ergonomi: Bireyin aktivitelerinin analizinin yapılması ve aktivitenin gerçekleştirilmesi için gereken doğru hareketin belirlenmesiyle bunun çözümü için gerekli olan çevresel düzenlenmelerin yapılması ya da yardımcı cihazların belirlenmesinde kullanılan prensipler bütünüdür (Dul, Bruder, Buckle ve ark, 2012; Salvendy, 2012).

Enerji Koruma: Bireyler günlük rutinleri içerisinde ya da ani olarak gerçekleştirmiş oldukları aktiviteler için belirli bir güç ve enerji sarf ederler. Enerji koruma ise belli prensipler kullanılarak sarf edilen enerjiyi azaltmak ve kişinin daha az yorulmasını sağlamaktır. Kullanılan ilkelerden bazıları şu şekildedir; işler için önceden plan yapma, kendi hızını denetleme, iş için öncelik belirleme, gereksiz işleri eleme, dinlenme ve aktivite zamanlarını dengede tutma ve aktivite dayanıkııı̆ını öğrenme (Hochberg, Altman, Brandt ve ark, 1995; Velloso \& Jardim, 2006).

Stres Yönetimi ve Stresle Başa Çıkma: Bireylerin gün içindeki psiko-sosyal etkilenimlerini ve stres seviyelerini azaltmak ve genel iyi olma halini korumak için uygulanan yöntemlerdir. En çok kullanılan yöntemler ise progresif gevşeme, solunum teknikleri ve yaşam tarzı değişikleri eğitimidir (Shapiro, Brown, \& Biegel, 2007).

Bakım veren bireyler için geliştirilen eğitim programlarına dayanan çalışmalar incelendiğinde; eğitim programlarının toplu olarak geliştirilip uygulandığı, eğitim programlarının uygulama yeri olarak ya çalışmanın yürütüldüğü merkezler ya da bakım veren bireylerin evleri olduğu tespit edildi (Broughton, Smith, Baker ve ark, 2011; Collins \& Swartz, 2011; Houts, Nezu, Nezu ve ark, 1996). Bu nedenle çalışmamız bireysel değerlendirmelerin ardından eğitim modeli oluşturma ve modelin uygulama sonuçlarını bireysel olarak incelemek amacıyla planlandı.

\section{GEREÇ VE YÖNTEM}

Çalışmamıza Hacettepe Üniversitesi Sağlık Bilimleri Fakültesi Ergoterapi Bölümü Erişkin Ünitesinde tedavi gören bireylerin bakım verenleri dahil edilmiştir. Çalışmamıza dâhil edilecek bakım 
verenlerin kriterleri şu şekilde belirlenmiştir;

- 18 yaşından büyük bir bireye bakım veriyor olmak

- Bakım verme işinden belli bir gelir elde ediyor olmamak

- Bakım verme konusunda daha önce eğitim almamış olmak

- Fonksiyonel Bağımsızlık Ölçeği (FBM) alt parametrelerinin hepsinden orta derece yardıml veya daha fazla yardıma ihtiyaç duyan bireylere bakım veriyor olmak

Çalışma dahil edilme kriterlerine uyan ve çalışmaya katılmaya gönüllü olan bireylere Helsinki Bildirgesine uygun bir şekilde aydınlatılmış onam formu hazırlandı. Çalışmaya katılan 14 bakım veren çalışma hakkında bilgilendikten sonra onam formunu imzaladı. Ancak bu bireylerden 9'u çalışmaya başladıktan ilk 4 haftada kişisel sebeplerden katılamayacaklarını beyan ettikleri için çalışmanın dışında bırakıldı. Çalışma 5 kişi ile tamamlandı. Birey merkezli değerlendirmeler, müdahale programları ve eğitim programları oluşturmak; grup temelli yöntemlerle kıyaslandığında daha detaylı analiz gerektirmektedir.

Çalışmamız iki ana bölümden oluşmaktadır. İlk bölüm bakım veren bireylerin sorunlarının tespitidir. İkinci bölüm ise bu sorunların giderilmesine yönelik bireyselleştirilmiş ergoterapi programlarının oluşturulması ve oluşturulan bireyselleştirilmiş ergoterapi eğitim programlarını etkinliğinin incelenmesidir.

\section{Sorun Tespiti \\ İlk bölümde kapsamında, bakım veren bireylerle Hacettepe Üniversitesi Ergoterapi Bölümü ünitelerinde yüz yüze görüşüldü ve değerlendirmeler uygulandı. Çalışmamızda yaşam kalitesini değerlendirmek amacıyla Nottingham Health Profile, bakım veren bireylerin depresyon ile kaygı düzeylerinin belirlenmesi için Beck Depresyon - Beck Anksiyete ölçekleri ve bakım veren bireylerin bakım verme işinden kaynaklanan yüklenmelerinin tespiti içinde Zarit Yük İndeksi kullanıldı.}

Nottingham Sağlık Profili (NSP): Sağlıkla ilgili yaşam kalitesini değerlendirmek için NSP'nin Türkçe versiyonu kullanılmıştır. NSP, kişinin algıladığı sağlık problemlerini ve bu problemlerin normal günlük aktiviteleri etkileme düzeyini ölçen, bir genel yaşam kalitesi anketidir. Anket, 38 maddeden oluşur ve sağlık statüsü ile ilgili altı parametrede değerlendirir. Bunlar; enerji (3 madde), ağrı (8 madde), emosyonel reaksiyonlar (9 madde), uyku (5 madde), sosyal izolasyon ( 5 madde) ve fiziksel aktivite ( 8 madde) şeklindedir. Sorulara evet veya hayır seklinde cevap verilir. Her bir bölüme 0-100 arası puanlama yapılır. 0 en iyi sağlık durumunu, 100 en kötü sağlık durumunu gösterir. Çalışma kapsamında NSP'nin alt skorları ve toplam NSP puanı değerlendirilmiştir. Toplam NSP puanı alt puanların toplamından elde edilmiştir (Hunt, Alonso, Bucquet ve ark, 1993; Kücükdeveci, McKenna, Kutlay ve ark, 2000).

Beck Depresyon Ölçeği (BDÖ): Beck tarafından 1961 'de geliştirilen ve ülkemizde geçerlik ve güvenirlik çalışmaları Teğin (1980), Hisli (1988) tarafından yapılan iç tutarlılığı yüksek $(\alpha=, 85)$ olan Beck Depresyon Ölçeği karamsarlık, başarısızlık duygusu, doyum almama, suçluluk duyguları, huzursuzluk, yorgunluk, iştah azalması, kararsızlık, uyku bozukluğu, sosyal çekilme gibi depresif belirtileri içeren 21 maddeden oluşmaktadır. Her madde depresyona özgü bir davranışı belirleyen dört dereceli kendini değerlendirme ifadesini içermektedir. Bireyler bu testten minimum "0" maksimum "63" üzerinden değerlendirilmektedirler (Hisli, 1988).

Beck Anksiyete Ölçeği (BAÖ): Bireyin yaşadığı anksiyete belirtilerinin sıklık düzeyini ölçen ve kanıt değerliliği yüksek olan( $\alpha=$,86) bir ölçektir. 21 maddeden oluşan, 0-3 arası puanlanan, bir kendini değerlendirme ölçeğidir. Toplam puanın yüksekliği kişinin yaşadığı anksiyetenin yüksekliğini gösterir ve "0 ile 63" arasında değişir. Beck ve arkadaşları (1988) tarafından geliştirilmiş olup ülkemizde geçerlilik ve güvenilirlik çalışması, Ulusoy ve arkadaşları (1998) tarafından yapılmıştır (Seber, Dilbaz, Kaptanoğlu ve ark, 1993).

Zarit Yük Indeksi (ZYí): Bu ölçek Zarit ve arkadaşları tarafından 1980 yılında geliştirilmiştir. Ülkemizde ise Özlü ve arkadaşları tarafından geçerlilik güvenilirlik çalışması yapılmıştır. Bakım gereksinimi olan bireye bakım verenlerin yaşadığı yüklenmeyi değerlendirmek amacıyla kullanılan bir ölçektir. Bakım verenlerin kendisi ya da araştırmacı tarafından sorularak doldurulabilen ölçek, bakım vermenin bireyin yaşamı üzerine olan etkisini belirleyen 22 sorudan oluşmaktadır. Ölçekte yer alan maddeler genellikle sosyal ve duygusal alana yönelik olup, ölçek puanının yüksek olması, yaşanılan problemin yüksek olduğunu göstermektedir. Puanlamada 5'li likert (0-4) skalası kullanılmıştır. Minimum "0" maksimum "84" puan üzerinden değerlendirme yapılmaktadır. Ölçeğin iç tutarlılık katsayısı 0,94 olarak bulunmuştur (George \& Gwyther, 1986; Ozer, Yurttaş, \& Akyil, 2012). 
Eğitim Programının Oluşturulması ve Uygulanması Elde edilen geri bildirimler ve değerlendirme testleri dikkate alınarak problem alanlarının çözümüne yönelik eğitim programı oluşturuldu. Eğitim programı beş alt eğitim modülünü içermektedir. Bu modüller; Ergonomik düzenlemeler ve eklem-enerji koruma teknikleri, yatak içi mobilizasyon yöntemleri, yatak içi bakım ve öz bakım teknikleri, gevşeme egzersizleri ve zaman yönetimi becerileri eğitimi şeklindedir.

Eğitim programının süresi 8 hafta boyunca haftada 1 saat olmak üzere toplam 8 saat olarak planlanmıştır. Modüllerin uygulama sırasına göre saat bazlı dağılımları şu şekildedir;

- Ergonomik düzenlemeler ve eklem enerji koruma teknikleri $=2$ saat

- Yatak içi mobilizasyon = 2 saat

- Yatak içi bakım = 1 saat

- Gevşeme teknikleri = 2 saat

- Zaman yönetimi $=1$ saat

Ergonomik Düzenleme ve Eklem Enerji Koruma Teknikleri

Bu modül iki saat olarak planlandı. İki saatin bir saati bakım veren bireylere ergonomik düzenlemelerin anlatılması ve bu düzenlemelerin uygulatıması; bir saati ise eklem enerji koruma tekniklerinin teorik eğitimi ve uygulamalı olarak yapılması şeklindedir.

Modülün ilk bölümünün sonunda bakım veren bireylerden bakım verme ortamında; kendilerine, bakım verdikleri bireye, bakım verme işine engel olan durumlara yönelik farkındalık geliştirmeleri beklenmektedir. Ayrıca basit ergonomik düzenlemeler yapacak donanımı kazanmaları beklenmektedir.

Modülün ikinci yarısı sonunda ise bakım veren bireylerden; bakım verme işinden kaynaklı fiziksel yüklenmeleri sonucunda oluşan sekonder kasiskelet sistemi şikâyetleriyle baş etmede kullanacakları eklem-enerji koruma tekniklerini uygulayabilmeleri ve karşılaşacakları diğer sorunlara göre adapte etmeleri beklenmektedir.

Yatak İçi Mobilizasyon Teknikleri

Modülde bakım veren bireye; bakım verme sürecinde kullanacağı bakım verilen bireyi yatak içinde doğru pozisyonlama, yatak içi transfer teknikleri, yataktan başka bir yere transfer teknikleri teorik ve uygulamalı olarak anlatıldı. Ardından simülasyon şeklinde kendi başına pratik etmesi ve zorlandığı yerleri belirlemesi istenilecektir. Son olarak bu konuların çözüm yolları hakkında tartışıldı. Eğitimin sonunda bakım veren bireyin vücut mekaniklerine uygun ve daha az enerji kullanarak transferleri yerine getirme becerisini kazanması beklenmektedir.

Yatak İ̧i Bakım Ve Evde Bakım Teknikleri

Bu modülde bakım veren bireye; ev içinde bakım verme esnasında günlük kişisel bakım, yemek yeme gibi bakım verilen bireyin bireysel ihtiyaçlarını giderirken kullanılan doğru yöntemler hakkında hem teorik hem uygulamalı eğitimi içermektedir. Eğitim sonunda bakım veren bireylerden, bakım verme işini iki taraf için, güvenli, kolay, yararlı bir düzeyde yapabiliyor ve karşılaştığı problemlere doğru, etkin çözümler üretebiliyor olmaları beklenilmektedir.

\section{Gevşeme Egzersizleri}

Bakım veren bireylerin bakım verme işinden kaynaklı olarak karşılaşıłıları zorluklarla başa çıkma, çözüm üretme ve uygulama boyutlarında yaşadıkları stres bireyleri psikososyal yönden olumsuz etkilemektedir. Yüklenmenin etkilerini azaltmak için planlanan bu modülde bireylere kendini düzenleme teknikleri çerçevesinde gevşeme egzersizleri anlatılacaktır. Bu eğitim sonunda bakım veren bireyden bu teknikleri kendi başına uygulaması ve yaşamış olduğu stresi azaltmak için kendine, bulunduğu ortama ve zamana adapte edebilme becerisinin kazanmış olması beklenilmektedir.

\section{Zaman Yönetimi}

Bakım veren bireyler bakım verme işine başladıktan sonra sahip oldukları sorumlulukları yerine getirmede, diğer aile bireyleriyle sağlıklı iletişim kurma ve vakit geçirme gibi alanlarda problem yaşadıkları tespit edilmiştir. Bu bağlamda modülde bakım veren bireylere günlük yapılacak sorumluluk çizelgesi oluşturma, öncelikleri belirleme gibi zaman yönetimi tekniklerinin eğitimi verildi. Modül sonunda bakım veren bireylerin, günlük yaşamlarında rol dengelerini sağlamaları, sorumluluklarını yerine getirme noktasında daha planlı olmaları beklenilmektedir.

Çalışmamızın ikinci kısmında bakım veren bireylere bireysel olarak hazırlanan eğitim programları hem bakım veren bireylerin evinde hem de Hacettepe Üniversitesi Ergoterapi Bölümü Ünitelerinde teorik ve pratik şekilde uygulanmıştır. Eğitim programlarının sonunda bireylere çalışmanın başında uygulanan değerlendirme testleri bir kez daha uygulanmıştır.

\section{Istatistiksel Analiz}

Elde edilen verilerin istatistiksel analizi IBM SPSS versiyon 22.0 programı kullanılarak yapılmıştır. Veri analizlerinde "Wilcoxon Eşleştirilmiş İki Örnek Testi" "Spearman Kolerasyon Testi" ile karşılaştırmalar yapıldı. Anlamlııı düzeyi $p<0,05$ olarak kabul edildi. 


\section{SONUÇLAR}

Sorun Tespiti için Yapılan Görüşmelerin İçerik Analizi "Her gün yatağa yattığımda başımdan kuyruk sokumuma kadar bir ağrı hissediyorum."

"Oğlumu yataktan kaldırmak gerçekten bir eziyet bana ."

"İnanın hiçbir şeye yetişemiyorum, günün nasıl geçtiğini anlamıyorum."

"Eşim ve diğer çocuğum sürekli şikâyet ediyorlar bizde insanız azıcık yüzünü görelim diyorlar."

"O kadar çok bunalıyorum ki bazen kendimi öldürmek istiyorum "

"Tam dinleneceğim diyorum gene bir şeyler çıkıyor." "Markete bile gidecek zamanım olmuyor, kızımın yatağı toplamak ve üzerini değiştirmek çok zamanımı alıyor."

Yapılan ilk değerlendirme sonuçlarına göre bireylerin depresyon ve anksiyete seviyeleri orta düzey, yüklenmeleri ise hafif düzeyde bulunuldu.

Bakım Veren Bireylerle Eğitim Sonunda Yapılan Görüşmenin İçerik Analizi
Bakım veren 1: Artık daha az yorulup daha rahat iş yapabileceğim. Ayrıca kendime daha çok zaman ayırmam gerektiğini artık öğrendim.

Bakım veren 2: İçinde bulunduğum durum yüzünden karamsar değilim. Geleceğe dair daha çok umudum var.

Bakım veren 3: Bakım verirken artık daha az zorlanıyorum. Bilmeden yaptığım yanlışlar beni bedensel olarak yoruyormuş.

Bakım veren 4: Hiçbir şeye yetişemiyorum düşüncesi kayboldu. Artık her şeye yetişebiliyor ve daha az yoruluyorum.

Bakım veren 5: Moralim yerine geldi. Kendimi daha güçlü hissediyorum.

\section{Eğitim Programının Uygulama Sonuçları}

Çalışmamıza fiziksel bakıma intiyaç duyan bireylere bakım veren 5 kadın birey dâhil edilmiştir. Çalışmaya katılan bireylerin yaş ortalaması 49,00 \pm 4,74 (min:43, max:55) yıl olarak bulunuldu. Bireylerin bireysel eğitim programları öncesi ve sonrası değerlendirme sonuçları Tablo1'de gösterildi.

Tablo 1. Eğitim Öncesi Ve Sonrası Değerlendirmeler

\begin{tabular}{lllll}
\hline & Eğitim Öncesi & Eğitim Sonrası & p & Z \\
\cline { 2 - 3 } & $\mathrm{X} \pm \mathrm{SS}$ & $\mathrm{X} \pm \mathrm{SS}$ & & $-1,89$ \\
\hline Nottingham Enerji & $43,52 \pm 35,84$ & $44,37 \pm 36,63$ & 0,06 & $-0,44$ \\
\hline Nottingham Ağrı & $34,23 \pm 26,93$ & $30,19 \pm 23,33$ & 0,65 & $-2,02$ \\
\hline Nottingham Emosyonel Reaksiyonlar & $66,24 \pm 15,47$ & $41,96 \pm 19,62$ & $0,04^{*}$ & $-1,34$ \\
\hline Nottingham Sosyal İzolasyon & $45,38 \pm 21,33$ & $33,08 \pm 30,48$ & 0,18 & $-2,04$ \\
\hline Nottingham Uyku & $75,25 \pm 16,59$ & $16,78 \pm 20,51$ & $0,04^{*}$ & $-2,00$ \\
\hline Nottingham Fiziksel Aktivite & $17,11 \pm 9,61$ & $17,18 \pm 16,39$ & 1,00 & 0,00 \\
\hline Nottingham Toplam & $281,75 \pm 33,01$ & $139,23 \pm 36,55$ & $0,04^{*}$ & $-2,02$ \\
\hline Beck Depresyon Ölçeği & $20,60 \pm 3,36$ & $14,40 \pm 2,60$ & $0,04^{*}$ & $-2,02$ \\
\hline Beck Anksiyete & $15,80 \pm 4,96$ & $12,00 \pm 6,44$ & 0,06 & $-1,84$ \\
\hline Zarit Yük İndeksi & $39,20 \pm 14,77$ & $32,80 \pm 11,75$ & $0,04^{*}$ & $-2,03$
\end{tabular}

${ }^{*} p<0,05$

Bakım veren bireylerin bireysel eğitim programları sonunda yaşam kalitelerindeki değişim profillerine göre; emosyonel reaksiyon ( NottinghamER), uyku (NottinghamU), ve genel yaşam kalitesinde (NotthingamT) istatistiksel olarak anlamlı $(p=0,043)$ bir iyileşme saptandı. Eğitim sonrası bireylerin depresyon düzeylerinde istatistiksel olarak anlamlı ( $p=0,041$ ) bir azalma tespit edildi. Bireylerin eğitim sonrası anksiyete düzeylerindeki değişimi ise istatistiksel açıdan anlamlı $(p=0,066)$ bulunmadı. Bakım veren bireylerin bakım verme işinden kaynaklı yüklenmelerinin ise eğitim öncesine ve sonras değerlendirme verileri karşılaştırıldığında istatistiksel olarak anlamlı $(p=0,042)$ bir şekilde azaldığı tespit edildi. Bu bağlamda bakım veren bireyler için bireysel olarak geliştirilmiş olan eğitim programları incelendiğinde, bakım veren bireylerin yaşam kalitelerini iyileştirme, depresyon düzeylerini azaltmada ve bakım verme işinden kaynaklı yüklenmelerini hafifletme noktasında olumlu etkisi olduğu ortaya konuldu. Ayrıca bakım veren bireylerin anksiyete puanlarının düştüğü görülmektedir. Bu düşüş istatistiksel olarak anlamlı bir değişim olmasa da çalışmaya katılan 2-4-5 numaralı bakım veren 
bireyler anksiyete düzeylerinin azaldığını ifade etmişlerdir. Bu da eğitim programlarının anksiyete düzeylerinin azaltılması noktasında olumlu etki yaptığını göstermektedir.

Bireysel eğitim sonunda bakım veren bireylerin cinsiyet, yaşam kalitesi, depresyon, anksiyete ve bakım veren yüklenmeleri arasındaki ilişkiye bakıldığında istatistiksel olarak anlamlı $(p>0,05)$ bir ilişki saptanmadı.

Tablo 2. Korelasyon tablosu

\begin{tabular}{|c|c|c|c|c|c|c|}
\hline & & Cinsiyet & NotthingamT & $\begin{array}{l}\text { Beck } \\
\text { Depresyon }\end{array}$ & $\begin{array}{l}\text { Beck } \\
\text { Anksiyete }\end{array}$ & $\begin{array}{l}\text { Zarit Yük } \\
\text { İndeksi }\end{array}$ \\
\hline \multirow[t]{2}{*}{ Cinsiyet } & $r$ & 0,00 & 0,00 & 0,00 & 0,00 & 0,00 \\
\hline & $p$ & 0,00 & 0,00 & 0,00 & 0,00 & 0,00 \\
\hline \multirow[t]{2}{*}{ NotthingamT } & $r$ & 0,00 & 1,00 & 0,50 & $-0,05$ & 0,30 \\
\hline & $p$ & 0,00 & 0,00 & 0,39 & 0,93 & 0,62 \\
\hline \multirow{2}{*}{$\begin{array}{l}\text { Beck } \\
\text { Depresyon }\end{array}$} & $r$ & 0,00 & 0,50 & 1,00 & $-0,61$ & 0,60 \\
\hline & $p$ & 0,00 & 0,39 & 0,00 & 0,26 & 0,28 \\
\hline \multirow[t]{2}{*}{ BeckAnksiyete } & $r$ & 0,00 & $-0,51$ & $-0,61$ & 1,00 & $-0,82$ \\
\hline & $p$ & 0,00 & 0,93 & 0,26 & 0,00 & 0,08 \\
\hline \multirow{2}{*}{$\begin{array}{l}\text { Zarit Yük } \\
\text { İndeksi }\end{array}$} & $r$ & 0,00 & 0,30 & 0,60 & $-0,82$ & 1,00 \\
\hline & $p$ & 0,00 & 0,62 & 0,28 & 0,08 & 0,00 \\
\hline
\end{tabular}

\section{TARTIŞMA}

Günümüzde sağlıkta yeni hizmet yaklaşımları pek çok kronik hastanın bakım intiyacının ağırlıklı olarak aile ve yakınları tarafından karşılanmasını da beraberinde getirmektedir. Bakım intiyacı olan bireylerin en çok çocuklar ve yaşlılar olmasının yanı sıra Alzheimer hastalığı, hemipleji, terminal kanser, kronik ruhsal bozukluklar, serebral-palsi, mental reterdasyon, kronik ostrüktif akciğer hastalığı ve parkinson, multiplskleroz gibi sağlık sorunlarında da bakım intiyacı olan bireylere de uzun dönem bakım gerekmektedir (Rodgers, Atkinson, Bond ve ark, 1999).

Hizmet alanlara rehabilitasyon hizmetleri sunulurken bakım verenlerin genellikle problem ve intiyaçları göz ardı edilerek yalnızca sağlık sorunu olan bireylere odaklanılmaktadır. Bu durum tıbbi modelin getirdiği bir yaklaşımdır. Ancak Dünya Sağlık Örgütü'nün son yıllardaki stratejileri ile birlikte birey merkezli müdahale programları ön plana çıkarak biyopsikososyal modelin pekişmesini sağlamıştır (Blendon, Kim, \& Benson, 2001). Peter ve arkadaşları yapmış oldukları çalışmada informal bakım veren bireylere uygulanan problem çözme eğimi sonrasında bakım veren bireylerin depresyon ve anksiyete düzeylerinin azalttıklarını bulmuşlardır (Houts ve ark, 1996). Çalışmamızda rehabilitasyon hizmeti alan bireyle, bakım verenlerle yapılan görüşmelerde literatürdeki örneklerine benzer biçimde bakım yükünün tükenmişlik, depresyon, yaşam kalitesinde azalma, yorgunluk, kas iskelet sistemi zorlanmaları ve katılım kısıtlılığını pekiştirdiği saptanmıştır.

Bakım verme yükünü etkileyen faktörler ve bakım verenlerin problem ve beklentilerinin tanımlandığı çok sayıda çalışma (Graff, VernooijDassen, Thijssen ve ark, 2007; Mollaoğlu, Tuncay, \& Fertelli, 2011; Park, Shin, Choi ve ark, 2012) yapılırken bakım veren yükünü azaltmaya yönelik müdahale programlarını içeren çalışmalar ise son derece kısıtıdır (Alnazly, 2016; Evans, Matlock, Bishop ve ark, 1988; Rodgers ve ark, 1999). Mevcut çalışmalar da farmakolojik tedaviler ve paket programlardan oluşmakta olup, bireylerin intiyacına göre özelleştirilmiş programlar değildir (Bergström ve ark, 2011; Cameron, Naglie, Green ve ark, 2015; Dooley \& Hinojosa, 2004). Birey merkezli olmayan programlarda kişilerin intiyaçları atlanabilmekte ve müdahale programları da yetersiz kalabilmektedir. Ayrıca paket programların uygulanabilmesi için homojen grup olması gerekmektedir ki bu da pratikte çok gerçekçi değildir. Çalışmamızda uygulamış olduğumuz eğitim programı ise tamamen bireylerin özgün ihtiyaçlarına göre düzenlenmiştir. Bu da bireysel sorunların çözümüne odaklanılmasını mümkün kılmıştır. Çalışmamızda bireysel uygulanan eğitim programının bireylerin bakım verme işinden kaynaklı yüklenmelerini azaltmakla kalmadığı 
yaşam kalitelerini de artırdığı görülmektedir. Ayrıca bireylerin depresyon seviyelerinde gözlenen anlamlı azalmada bireylerin eğitim programı sonunda verdikleri geri bildirimlere yansımıştır.

Çalışmamızın gereç ve yöntemi planlanırken; oluşturulması düşünülen eğitim programının bireye özgü bir şekilde geliştirilmesi ve çalışmada yer alan araştırmacıların iş yükleri de göz önünde bulundurulduğunda sayının 5 kişide tutulması kararlaştırıldı. Bu yüzden niceliksel örneklem büyüklüğü hesabı yapılmamıştır. Bu durum örneklem büyüklüğünün seçilimi noktasında çalışmamızın limitasyonudur.

Çalışmamızda bireylerin depresyon, anksiyete, yaşam kalitesi ve yüklenmeleri arasında istatistiksel olarak anlamlı bir ilişki bulunamadı. Buna karşın nitel görüşmelerden elde edilen bakım veren geri bildirimlerine bakıldığında, bireylerin bu performans alanlarında iyileşme kaydettikleri görülmektedir. İstatistiksel olarak anlamlı bir sonucun yakalanamamasının sebebinin; birey merkezli eğitim programı oluşturulduğundan örneklem büyüklüğü sınırlı tutulması ve aradaki ilişki istatistiksel olarak gösterebilecek yeterli örneklem grubuna ulaşılamamasından kaynaklı olduğu düşünülmektedir.

Bakım veren bireyler bakım verme işine informal olarak başladıktan sonra fiziksel ve psikolojik bir yüklenmeye maruz kalmaktadırlar (Chang ve ark, 2010; Stephens, Townsend, Martire ve ark, 2001). Bu durumda bireylerin aktivite rol dengesi ve katılımı kısıtlanmasına neden olmaktadır (Stephens ve ark, 2001). Bakım veren bireyler için hazırlanacak bireysel eğitim programları bireylerin bakım vermeye bağlı diğer problemlerin azaltılmasında önemli rol oynamaktadır (Davis, Shelly, Waters ve ark, 2010). $\mathrm{Bu}$ problemlerin azaltılması bakım veren bireylerin fiziksel ve mental iyi olma halinin artırılması ve sosyal katılımlarını desteklemektedir. Bu alanda yapılacak olan çalışmaların yaygınlaşarak daha çok profesyonelin ortak yürüttüğü okul şeklinde bir uygulamaya dönüşerek toplumsal politika stratejilerinde yer alması, bakım veren bireylerin sorunlarının çözülmesi noktasında önemli bir adım olacaktır.

\section{Kaynaklar}

Alnazly, E. (2016). Coping strategies and socio-demographic characteristics among Jordanian caregivers of patients receiving hemodialysis. Saudi Journal of Kidney Diseases and Transplantation, 27(1), 101.

Bergström, A. L., Eriksson, G., von Koch, L., \& Tham, K. (2011). Combined life satisfaction of persons with stroke and their caregivers: associations with caregiver burden and the impact of stroke. Health and quality of life outcomes, 9(1), 1.

Bevans, M., \& Sternberg, E. M. (2012). Caregiving burden, stress, and health effects among family caregivers of adult cancer patients. Jama, 307(4), 398-403.

Blendon, R. J., Kim, M., \& Benson, J. M. (2001). The public versus the World Health Organization on health system performance. Health affairs, 20(3), 10-20.

Broughton, M., Smith, E. R., Baker, R., Angwin, A. J., Pachana, N. A., Copland, D. A., et al. (2011). Evaluation of a caregiver education program to support memory and communication in dementia: A controlled pretest-posttest study with nursing home staff. International Journal of Nursing Studies, 48(11), 1436-1444.

Cameron, J. I., Naglie, G., Green, T. L., Gignac, M. A., Bayley, M., Huijbregts, M., et al. (2015). A feasibility and pilot randomized controlled trial of the "Timing it Right Stroke Family Support Program". Clinical rehabilitation, 29(11), 1129-1140.

Chang, H.-Y., Chiou, C.-J., \& Chen, N.-S. (2010). Impact of mental health and caregiver burden on family caregivers' physical health. Archives of gerontology and geriatrics, 50(3), 267-271.

Collins, L. G., \& Swartz, K. (2011). Caregiver care. American family physician, 83(11), 1309

Davis, E., Shelly, A., Waters, E., Boyd, R., Cook, K., \& Davern, $M$. (2010). The impact of caring for a child with cerebral palsy: quality of life for mothers and fathers. Child: care, health and development, 36(1), 63-73.

Dooley, N. R., \& Hinojosa, J. (2004). Improving quality of life for persons with Alzheimer's disease and their family caregivers: Brief occupational therapy intervention. American Journal of Occupational Therapy, 58(5), 561569.

Dul, J., Bruder, R., Buckle, P., Carayon, P., Falzon, P., Marras, W. S., et al. (2012). A strategy for human factors/ergonomics: developing the discipline and profession. Ergonomics, 55(4), 377-395.

Evans, R. L., Matlock, A.-L., Bishop, D. S., Stranahan, S., \& Pederson, C. (1988). Family intervention after stroke: does counseling or education help? Stroke, 19(10), 12431249.

Faria, S. H. (1998). Through the eyes of a family caregiver. Part 2: Strategies to manage caregiver problems. Home care provider, 3(5), 271-275.

George, L. K., \& Gwyther, L. P. (1986). Caregiver weil-being: A multidimensional examination of family caregivers of demented adults. The Gerontologist, 26(3), 253-259.

Given, C. W., Given, B., Stommel, M., Collins, C., King, S., \& Franklin, S. (1992). The caregiver reaction assessment (CRA) for caregivers to persons with chronic physical and mental impairments. Research in nursing \& health, 15(4), 271-283.

Graff, M. J., Vernooij-Dassen, M. J., Thijssen, M., Dekker, J., Hoefnagels, W. H., \& OldeRikkert, M. G. (2007). Effects of community occupational therapy on quality of life, mood, and health status in dementia patients and their caregivers: a randomized controlled trial. The Journals of Gerontology Series A: Biological Sciences and Medical Sciences, 62(9), 1002-1009.

Hisli, N. (1988). Beck Depresyon Ölçeği'nin bir Türk örnekleminde geçerlilik ve güvenilirliği. Psikoloji Dergisi, 6 , 118-122.

Hochberg, M. C., Altman, R. D., Brandt, K. D., Clark, B. M., Dieppe, P. A., Griffin, M. R., et al. (1995). Guidelines for the medical management of osteoarthritis. Arthritis \& Rheumatology, 38(11), 1535-1540.

Houts, P. S., Nezu, A. M., Nezu, C. M., \& Bucher, J. A. (1996). The prepared family caregiver: a problem-solving approach to family caregiver education. Patient education and counseling, 27(1), 63-73.

Hunt, S., Alonso, J., Bucquet, D., Niero, M., Wiklund, I., \& McKenna, S. (1993). European Group for Quality of life, assessment and health measurement. European Guide to 
the Nottingham Health Profile. Brookwood Medical publication: Surrey.

Kücükdeveci, A., McKenna, S., Kutlay, S., Gürsel, Y., Whalley, D., \& Arasil, T. (2000). The development and psychometric assessment of the Turkish version of the Nottingham Health Profile. International journal of rehabilitation research. Internationale Zeitschrift fur Rehabilitationsforschung. Revue internationale de recherches de readaptation, 23(1), 31-38.

Lui, M. H. L., Lee, D. T., Greenwood, N., \& Ross, F. M. (2012). Informal stroke caregivers' self-appraised problem-solving abilities as a predictor of well-being and perceived social support. Journal of clinical nursing, 21(1-2), 232-242.

Mollaoğlu, M., Tuncay, F. Ö., \& Fertelli, T. K. (2011). İnmeli hasta bakım vericilerinde bakım yükü ve etkileyen faktörler. Dokuz Eylül Üniversitesi Hemşirelik Yüksek Okulu E-Dergi, 4(3), 125-130.

Morimoto, T., Schreiner, A. S., \& Asano, H. (2003). Caregiver burden and health-related quality of life among Japanese stroke caregivers. Age and Ageing, 32(2), 218-223.

Ozer, N., Yurttaş, A., \& Akyil, R. Ç. (2012). Psychometric evaluation of the Turkish version of the Zarit Burden Interview in family caregivers of inpatients in medical and surgical clinics. Journal of transcultural nursing: official journal of the Transcultural Nursing Society, 23(1), 65-71.

Park, C. H., Shin, D. W., Choi, J. Y., Kang, J., Baek, Y. J., Mo, H. N., et al. (2012). Determinants of the burden and positivity of family caregivers of terminally ill cancer patients in Korea. Psycho-Oncology, 21(3), 282-290.

Rodgers, H., Atkinson, C., Bond, S., Suddes, M., Dobson, R. \& Curless, R. (1999). Randomized controlled trial of a comprehensive stroke education program for patients and caregivers. Stroke, 30(12), 2585-2591.

Salvendy, G. (2012). Handbook of human factors and ergonomics: John Wiley \& Sons.

Seber, G., Dilbaz, N., Kaptanoğlu, C., \& Tekin, D. (1993) Umutsuzluk ölçeği: Geçerlilik ve güvenirliği. Kriz Dergisi, 1(3), 139-142.

Shapiro, S. L., Brown, K. W., \& Biegel, G. M. (2007). Teaching self-care to caregivers: Effects of mindfulness-based stress reduction on the mental health of therapists in training. Training and education in professional psychology, 1(2), 105.

Stephens, M. A. P., Townsend, A. L., Martire, L. M., \& Druley, J. A. (2001). Balancing parent care with other roles: Interrole conflict of adult daughter caregivers. The Journals of Gerontology Series B: Psychological Sciences and Social Sciences, 56(1), P24-P34.

Thompson Jr, E. H., Futterman, A. M., Gallagher-Thompson D., Rose, J. M., \& Lovett, S. B. (1993). Social support and caregiving burden in family caregivers of frail elders. Journal of Gerontology, 48(5), S245-S254.

Toseland, R. W., Rossiter, C. M., Peak, T., \& Smith, G. C. (1990). Comparative effectiveness of individual and group interventions to support family caregivers. Social Work, 35(3), 209-217.

Velloso, M., \& Jardim, J. R. (2006). Study of energy expenditure during activities of daily living using and not using body position recommended by energy conservation techniques in patients with COPD. Chest, 130(1), 126-132.

Zarit, S. H., Todd, P. A., \& Zarit, J. M. (1986). Subjective burden of husbands and wives as caregivers: A longitudinal study. The Gerontologist, 26(3), 260-266. 